\title{
Assessment of Air pollution Tolerance Index of some selected plants of Golapbag Campus of Burdwan University, Burdwan in West Bengal
}

\author{
Moumita Das, Sharmistha Ganguly, Swastika Banerjee, Ambarish Mukherjee \\ CAS, Department of Botany, Burdwan University, Golapbag, Burdwan- 713104, West Bengal, India
}

\begin{abstract}
From the greenery of Golapbag campus of Burdwan University as many as 10 non-ligneous species were selected for determining their Air Pollution Tolerance Index (APTI). While determining the APTI values, chlorophyll content was found to range from $0.007 \mathrm{mg} / \mathrm{g}$ (Desmodium gangeticum) to $0.843 \mathrm{mg} / \mathrm{g}$ (Boerhavia repens), relative water content from $69.82 \%$ (Boerhavia repens) to $92.4 \%$ (Elephantopus scaber); ascorbic acid from $42.105 \mathrm{ppm}$ (Elephantopus scaber) to $71.05 \mathrm{ppm}$ (Antigonon leptopus) and leaf pH from 3.53 (Vitis reticulatus) to 8.16 (Ruelia tuberosa). APTI values ranged from 32.66 (Vitis reticulatus) to 61.20 (Antigonon leptopus), thus indicating all selected species to be highly tolerant to air pollution, hence suitable for greening parks and gardens in polluted areas.
\end{abstract}

Keywords: Air Pollution Tolerance Index, Ascorbic acid, Biomonitoring, Elephantopus scaber, Relative water content.

\section{Introduction}

Biomonitoring of environmental state in temporal and spatial scales is considered essential for optimizing the life sustaining system of the Earth. Biomonitoring is prioritized over physical monitoring systems since living organisms themselves fall victim to pollution and have no other alternative than to offer resilience by their life strategy, endurance and adaptive credentials. Among all organisms plants are more suitable in biomonitoring programmes since they are more sensitive especially to air pollution and being stationary they are able to maintain diaries of age-long environmental experience (Mukherjee, 1993). Plants provide enormous leaf area for impingement, absorption and accumulation of air pollutants to reduce the pollution level in the air environment (Escobedo et al., 2008). Parameters like relative water content, $\mathrm{pH}$, chlorophyll and ascorbic acid in the leaves are pollution responsive and collectively useful in determination of Air Pollution Tolerance Index of plants which gives a clue whether the plant is sensitive or tolerant for use in biomonitoring of air pollution (Mashita and Pise, 2001). Air pollutant may get adsorbed, accumulated or integrated in the plant body system and if toxic, may injure them in various ways. The level of injury will be high in sensitive species and low in tolerant ones. The sensitive species help in indicating air pollution and tolerant one help in abatement of air pollution (Subrahmanyam et al., 1985). The plant species which are tolerant to pollution can function well as scavengers of air pollution. The aim of the present study was to evaluate impact of air pollution on relative water content, $\mathrm{pH}$, chlorophyll and ascorbic acid content of leaves of selected plant species growing in the Golapbag Campus and determine their Air Pollution Tolerance Index (APTI) so that the findings can be utilized in the selection of species for urban ground-greening elsewhere.

\section{Study Site}

Golapbag is the academic campus of Burdwan University with a greenery of admiration which at one time happened to be the royal garden of the Maharaja of Barddhaman (Burdwan). It is located at $23.25 \mathrm{~N} 87.85$ E with an average elevation of 40 meters $(131 \mathrm{ft})$ above the mean sea level. Golapbag or the garden of roses is a beautiful place which was established in 1884 as the botanical and zoological garden by the King Bijoy Chand Mahatab with technical advice from the then British experts in the subject. The famous botanist Sir J. D Hooker had paid a visit to the area and enlisted 128 types of trees for sustenance. The plants of the campus (Namhata and Mukherjee, 1990) and various environmental perspectives of the trees of the campus have evoked much interest for scientific investigation (Ghosh and Mukherjee, 2003; Hotwani and Mukherjee, 2005a and b; Das and Mukherjee, 2015; Ganguly and Mukherjee, 2016). The present study, new of its kind for the area, deals with 10 non-ligneous species of Angiosperms which are very common in the campus. 


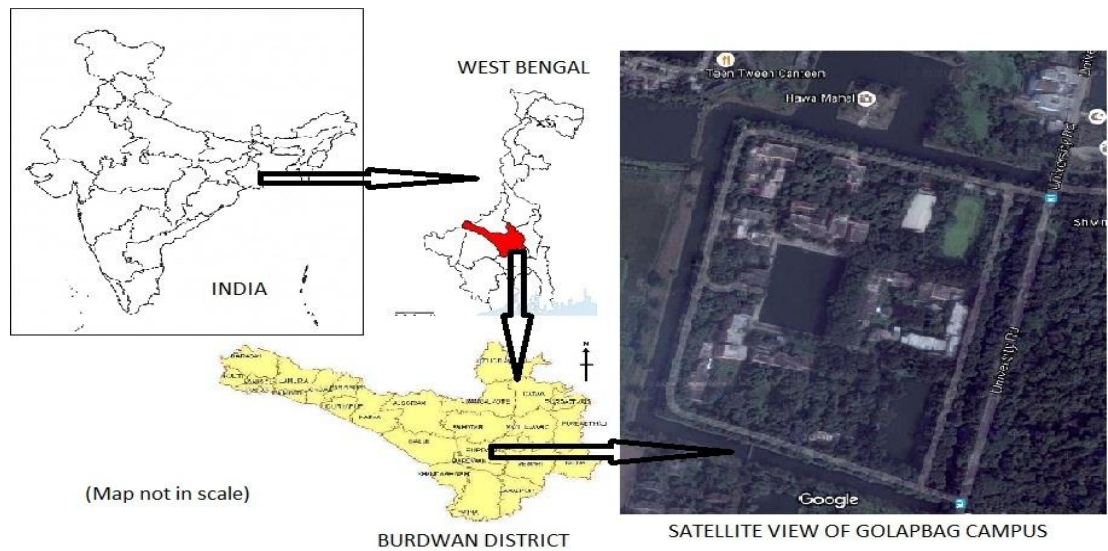

Figure 1: Study site and its location in Burdwan district of West Bengal state, India

\section{Material and Methods}

Ascorbic acid contents in ( $\mathrm{mg} / \mathrm{g}$ of dry weight), total chlorophyll (mg/g fresh weight), $\mathrm{pH}$ of leaf extract and relative water content are the parameters that are essential for determination of APTI, an index to evaluate the resistivity and susceptibility of plant species to pollution . In plant system Ascorbic acid (Vitamin C) is important in cell wall synthesis, carbon fixation during photosynthesis and cell division (Conklin, 2001) whereas $\mathrm{pH}$ act as an indicator for sensitivity to air pollution (Scholz and Reck, 1977). Total chlorophyll content is associated with ascorbic acid productivity.

\subsection{Total Chlorophyll content (Photosynthetic pigment)}

According to Arnon (1949) the concentration of chlorophyll was determined. $3 \mathrm{~g}$ of fresh leaves were blended and extracted with $10 \mathrm{ml}$ of $80 \%$ acetone and left for 15 minutes for thorough extraction. The liquid portion was decanted into another test tube and centrifuged at 2,500 rpm for 3 minutes. The supernatant was collected and then the absorbance was taken with a Beckman Spectrophotometer at 663 and $645 \mathrm{~nm}$ and using simultaneous equations as given by Mac Kinney (1941).

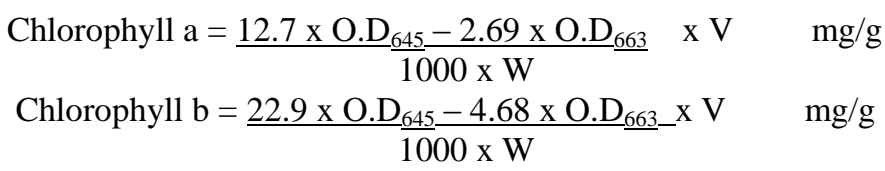

Total chlorophyll content $(\mathrm{TCh})=$ Chlorophyll $\mathrm{a}+$ Chlorophyll b $(\mathrm{mg} / \mathrm{g})$

$\mathrm{V}=$ Total volume of the chlorophyll solution $(\mathrm{ml})$

$\mathrm{W}=$ Weight of the tissue extracted $(\mathrm{g})$

\subsection{Relative water content (RWC)}

Fresh weight was obtained by weighing the fresh leaves. The samples were then immediately hydrated to full turgidity under normal room light and temperature over night. After hydration the samples were taken out of water and were well dried quickly and lightly with tissue paper and immediately weighed to obtain fully turgid weight (TW). Samples were then oven dried at $80^{\circ} \mathrm{C}$ for $24 \mathrm{~h}$ and weighed (after being cooled down in a desiccator) to determine dry weight (DW) (Barrs and Weatherley, 1962).

Relative water content (RWC):

$\mathrm{RWC}=[\mathrm{FW}-\mathrm{DW}) /(\mathrm{TW}-\mathrm{DW})] \times 100$

$\mathrm{FW}=$ fresh weight,

$\mathrm{DW}=$ dry weight

and $\mathrm{TW}=$ turgid weight.

\subsection{Leaf extracts pH}

1 gram of the leaves were homogenized in $10 \mathrm{ml}$ deionized water and centrifuged at 2,500 $\mathrm{rpm}$ for 3 minutes, then filtered and the $\mathrm{pH}$ of filtered leaf extract was determined by using $\mathrm{pH}$ meter. Extract $\mathrm{pH}$ was measured using $\mathrm{pH}$ meter which was calibrated using the buffer solutions of $\mathrm{pH} 4$ and $\mathrm{pH} 9$.

\subsection{Ascorbic acid content (AA)}

Ascorbic acid content (expressed in $\mathrm{mg} / \mathrm{g}$ ) was measured using spectrophotemetric method (Jagota and Dani, 1982).1 $\mathrm{g}$ of the fresh foliage leaves was homogenized with $10 \mathrm{ml}$ of $6 \%$ trichloroacetic acid (TCA) with 
the help of mortar and pestle and centrifuged at $5000 \mathrm{rpm}$ for 5 minutes. The supernatant was taken and a pinch of activated charcoal was added and filtered. The volume of the filtrate was made up to $100 \mathrm{ml}$ with distilled water. $5 \mathrm{ml}$ of supernatant was mixed with $3 \mathrm{ml}$ of $2 \% 2,4-\mathrm{DNPH}$ in $9(\mathrm{~N}) \mathrm{H}_{2} \mathrm{SO}_{4}$ and to it 1-2 drops of $10 \%$ thiourea solution in $70 \%$ ethanol was added and was boiled for 15 minutes in water bath and cooled in room temperature. To each sample $5 \mathrm{ml}$ of $80 \% \mathrm{H}_{2} \mathrm{SO}_{4}$ was added at $0^{\circ} \mathrm{C}$. After 30 minutes the absorbance was measured at $530 \mathrm{~nm}$ with a colorimeter. The concentration of unknown samples was extrapolated from a standard ascorbic acid solution of 50ppm using the formula:

Concentration of unknown solution $=\underline{\text { Concentration of standard solution } \times O_{\text {O. }}} \underline{530}_{\underline{0}}$ of unknown

\subsection{Formula of APTI used is given below}

O.D ${ }_{530}$ of standard solution

APTI of tree species has been calculated by the following formula proposed by Singh and Rao (1983).

$\mathrm{APTI}=\frac{\mathrm{A}(\mathrm{T}+\mathrm{P})+\mathrm{R}}{10}$

Where, $\mathrm{A}=\quad$ ascorbic acid contents in $\mathrm{mg} / \mathrm{g}$ of dry weight

$\mathrm{T}=\quad$ total chlorophyll in $\mathrm{mg} / \mathrm{g}$ fresh weight

$\mathrm{P}=\mathrm{pH}$ of leaf extract

$\mathrm{R}=\quad$ relative water content $(\%)$

Based on the APTI values the plants were conveniently grouped into categories as mentioned in the following (Kalyani and Singaracharya, 1995):

APTI value Response

30 to $100=$ Tolerant

29 to17= Intermediate

16 to $1=$ Sensitive

$<1=$ Very sensitive

\section{Result and Discussion}

The highest chlorophyll value of content was detected in leaves of Desmodium gangeticum and the lowest in Boerhavia repens (Table 1) which ranged from $0.007 \mathrm{mg} / \mathrm{g}$ to $0.843 \mathrm{mg} / \mathrm{g}$ (Fig.2). The variation in total chlorophyll content is likely to have been affected by the leaf- $\mathrm{pH}$.

Table 1: Chlorophyll contents of leaves of the species selected for the present study

\begin{tabular}{|c|c|c|c|c|}
\hline $\begin{array}{l}\text { Sl. } \\
\text { No. }\end{array}$ & $\begin{array}{l}\text { Name of the species } \\
\text { (Family) }\end{array}$ & $\begin{array}{l}\text { Chlorophyll } \\
\text { a (Chl a) }\end{array}$ & $\begin{array}{l}\text { Chlorophyll } \\
\text { b (Chl b) }\end{array}$ & $\begin{array}{l}\text { Total Chlorophyll } \\
(\text { Tch= Chl a+ Chl b) }\end{array}$ \\
\hline 1 & Alternanthera sessilis (L.) R.Br. ex DC. & 0.003 & 0.005 & 0.008 \\
\hline 2 & Antigonon leptopus Hook. \& Arn. & 0.231 & 0.420 & 0.651 \\
\hline 3 & Boerhavia repens $\mathrm{L}$. & 0.002 & 0.005 & 0.007 \\
\hline 4 & Desmodium gangeticum (L.) DC. & 0.299 & 0.544 & 0.843 \\
\hline 5 & Elephantopus scaber $\mathrm{L}$. & 0.060 & 0.110 & 0.170 \\
\hline 6 & Globba bulbifera Roxb. & 0.002 & 0.004 & 0.006 \\
\hline 7 & Oplismenus compositus (L.) P.Beauv. & 0.031 & 0.058 & 0.089 \\
\hline 8 & Ruellia tuberosa $\mathrm{L}$. & 0.144 & 0.263 & 0.407 \\
\hline 9 & Tridax procumbens (L.) L. & 0.010 & 0.018 & 0.028 \\
\hline 10 & Vitis reticulata M.A. Lawson & 0.024 & 0.045 & 0.069 \\
\hline
\end{tabular}

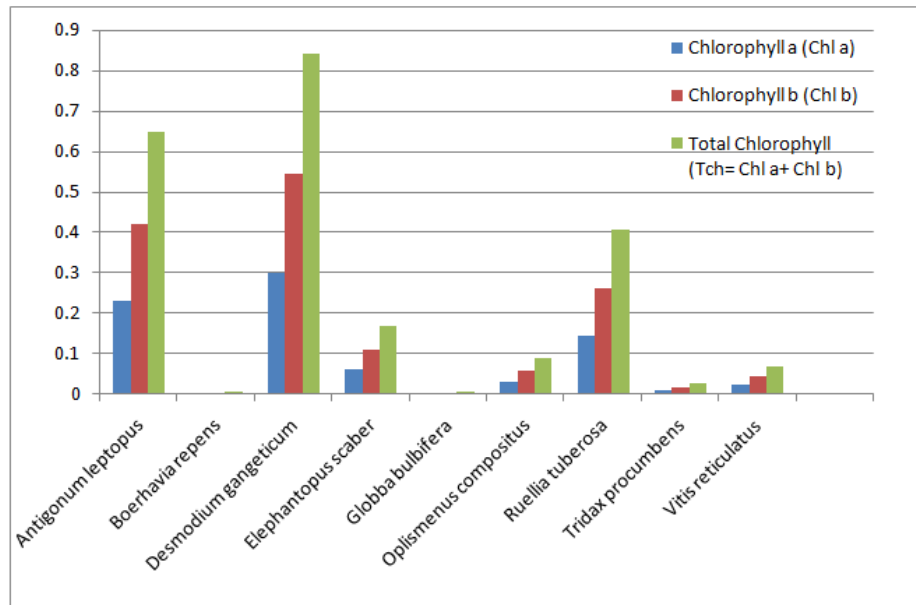

Figure 2: Bar graph represents the Chlorophyll a, Chlorophyll b and Total chlorophyll contents of the Plant species. 
The relative water content of the leaves which is the indicator of the plant water status ranged from 69.82 to $92.4 \%$ among the ten species (Table 2). Highest value was found in case of Elephantopus scaber and the lowest in Boerhavia repens (Fig.3). Relative water content is negatively related with $\mathrm{p}^{\mathrm{H}}$ because greater water content dilutes the acidic condition of leaves. High water content within a plant body helps to maintain its physiological balance under stress condition such as exposure to air pollution when the transpiration rates are usually high. High RWC favors drought resistance in plants (Dedio, 1975), as seen in Elephantopus scaber.

Table 2: Relative water contents of leaves of the species selected for the present study

\begin{tabular}{|c|c|c|c|c|c|c|c|c|}
\hline \multirow[t]{2}{*}{ Sl. No. } & \multirow[t]{2}{*}{ Name of the species } & \multicolumn{2}{|c|}{ Fresh weight (FW) g } & \multicolumn{2}{|c|}{ Turgid weight (TW) g } & \multicolumn{2}{|c|}{ Dry weight (DW) g } & \multirow{2}{*}{$\begin{array}{l}\text { Relative water } \\
\text { content } \\
\text { (RWC) \% }\end{array}$} \\
\hline & & Replica & Mean & Replica & Mean & Replicas & Mean & \\
\hline \multirow[t]{3}{*}{1} & \multirow{3}{*}{$\begin{array}{l}\text { Alternanthera sessilis } \\
\text { (L.) R.Br. ex DC. }\end{array}$} & 0.486 & \multirow[t]{3}{*}{0.291} & 0.546 & \multirow[t]{3}{*}{0.324} & 0.060 & \multirow[t]{3}{*}{0.039} & \multirow[t]{3}{*}{88.42} \\
\hline & & 0.242 & & 0.268 & & 0.34 & & \\
\hline & & 0.146 & & 0.160 & & 0.024 & & \\
\hline \multirow[t]{3}{*}{2} & \multirow{3}{*}{$\begin{array}{l}\text { Antigonon leptopus } \\
\text { Hook. \& Arn. }\end{array}$} & 0.377 & \multirow[t]{3}{*}{0.45} & 0.462 & \multirow[t]{3}{*}{0.555} & 0.110 & \multirow[t]{3}{*}{0.137} & \multirow[t]{3}{*}{74.88} \\
\hline & & 0.471 & & 0.585 & & 0.141 & & \\
\hline & & 0.502 & & 0.620 & & 0.161 & & \\
\hline \multirow[t]{3}{*}{3} & \multirow[t]{3}{*}{ Boerhavia repens $\mathrm{L}$. } & 0.210 & \multirow[t]{3}{*}{0.24} & 0.291 & \multirow[t]{3}{*}{0.326} & 0.036 & \multirow[t]{3}{*}{0.041} & \multirow[t]{3}{*}{69.82} \\
\hline & & 0.244 & & 0.316 & & 0.043 & & \\
\hline & & 0.268 & & 0.373 & & 0.045 & & \\
\hline \multirow[t]{3}{*}{4} & \multirow{3}{*}{$\begin{array}{l}\text { Desmodium } \\
\text { gangeticum (L.) DC. }\end{array}$} & 0.261 & \multirow[t]{3}{*}{0.294} & 0.309 & \multirow[t]{3}{*}{0.35} & 0.108 & \multirow[t]{3}{*}{0.112} & 76.47 \\
\hline & & 0.262 & & 0.321 & & 0.096 & & \\
\hline & & 0.359 & & 0.421 & & 0.133 & & \\
\hline 5 & Elephantopus scaber & 0.351 & 0.352 & 0.375 & 0.375 & 0.072 & 0.072 & 92.4 \\
\hline & & 0.370 & & 0.390 & & 0.077 & & \\
\hline & & 0.337 & & 0.362 & & 0.069 & & \\
\hline 6 & bulbifera & 0.431 & 0.484 & 0.480 & 0.535 & 0.082 & 0.087 & 88.61 \\
\hline & Roxb. & 0.516 & & 0.589 & & 0.086 & & \\
\hline & & 0.505 & & 0.538 & & 0.095 & & \\
\hline 7 & Oplismenus & 0.094 & 0.106 & 0.111 & 0.122 & 0.023 & 0.023 & 83.83 \\
\hline & compositus & 0.112 & & 0.127 & & 0.024 & & \\
\hline & P.Beauv. & 0.113 & & 0.130 & & 0.024 & & \\
\hline 8 & Ruellia tuberosa $\mathrm{L}$. & 0.327 & 0.274 & 0.361 & 0.298 & 0.082 & 0.063 & 89.78 \\
\hline & & 0.195 & & 0.214 & & 0.046 & & \\
\hline & & 0.302 & & 0.320 & & 0.063 & & \\
\hline 9 & Tridax procumbens & 0.185 & 0.218 & 0.226 & 0.26 & 0.019 & 0.022 & 82.35 \\
\hline & (L.) L. & 0.243 & & 0.274 & & 0.027 & & \\
\hline & & 0.228 & & 0.280 & & 0.022 & & \\
\hline 10 & Vitis reticulata M.A. & 0.993 & 1.092 & 1.086 & 1.191 & 0.200 & 0.214 & 89.86 \\
\hline & Lawson & 1.079 & & 1.174 & & 0.206 & & \\
\hline & & 1.206 & & 1.315 & & 0.238 & & \\
\hline
\end{tabular}

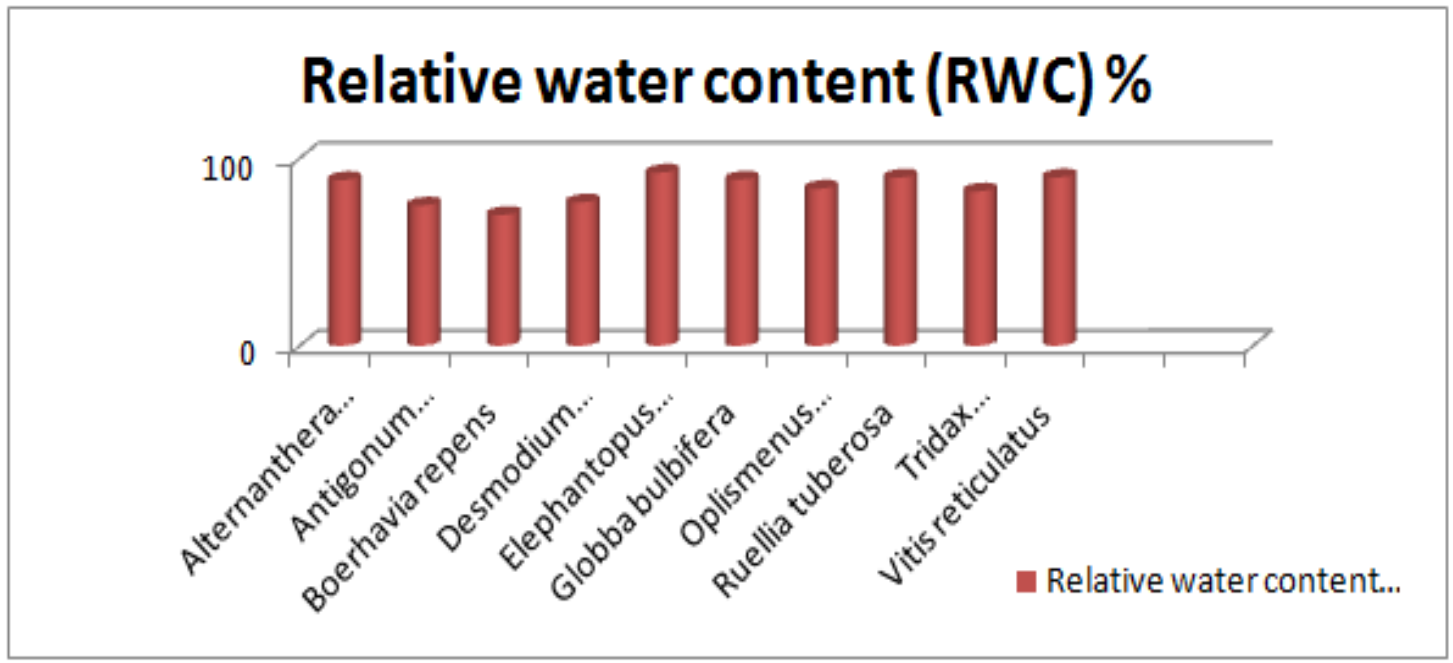

Figure 3: Bar graph represents the Relative water content of the Leaves.

Ascorbic acid is a stress reducing agent associated with tolerant species which reduces the effect of $\mathrm{SO}_{2}$ and act as antioxidant. In the present study ascorbic acid varied from $42.105 \mathrm{ppm}$ to $71.05 \mathrm{ppm}$ with Elephantopus scaber having lowest and Antigonon leptopus having highest content. 
Table 3: Analysis of Ascorbic acid content of leaves of the species selected for the present study

\begin{tabular}{|l|l|l|l|}
\hline Sl. No. & Name of the species & $\mathbf{O . D}_{\mathbf{5 3 0}} \mathbf{( \mathbf { n m } )}$ & $\begin{array}{l}\text { Ascorbic acid Concentration } \\
(\mathbf{p p m})\end{array}$ \\
\hline 1 & Alternanthera sessilis (L.) R.Br. ex DC. & 0.105 & 55.26 \\
\hline 2 & Antigonon leptopus Hook. \& Arn. & 0.135 & 71.05 \\
\hline 3 & Boerhavia repens L. & 0.105 & 55.26 \\
\hline 4 & Desmodium gangeticum (L.) DC. & 0.10 & 52.63 \\
\hline 5 & Elephantopus scaber L. & 0.08 & 42.105 \\
\hline 6 & Globba bulbifera Roxb. & 0.11 & 57.89 \\
\hline 7 & Oplismenus compositus (L.) P.Beauv. & 0.10 & 52.63 \\
\hline 8 & Ruellia tuberosa L. & 0.105 & 55.26 \\
\hline 9 & Tridax procumbens (L.) L. & 0.10 & 52.63 \\
\hline 10 & Vitis reticulata M.A. Lawson & 0.125 & 65.78 \\
\hline
\end{tabular}

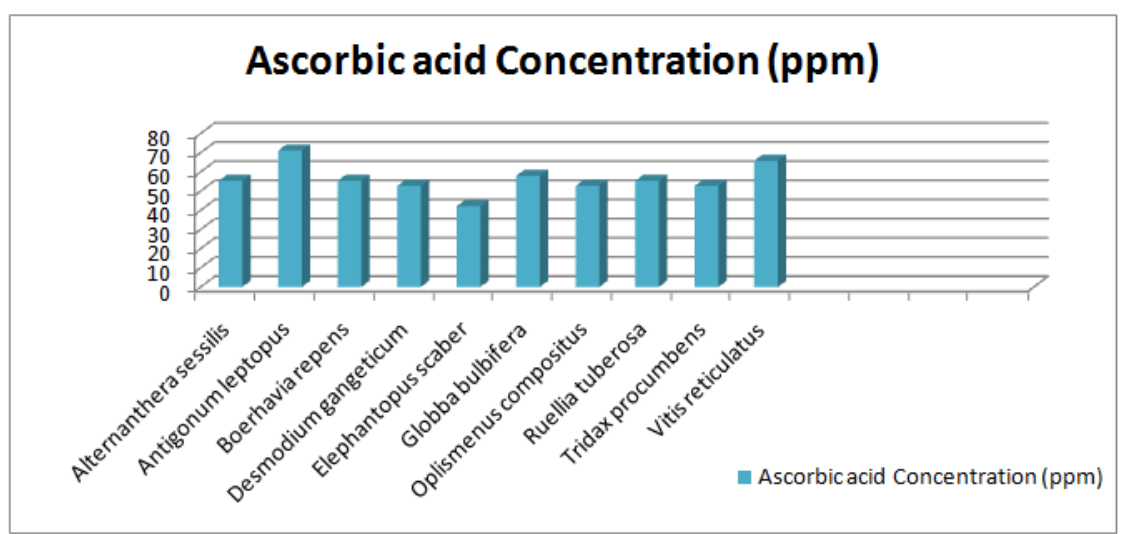

Figure 4: Bar graph represents the ascorbic acid concentration of the Leaves

Values of $\mathrm{pH}$ of leaf extracts ranges from 3.53 to 8.16 (Table 4) with Ruellia tuberosa scoring highest value and Vitis reticulatus the lowest (Fig. 5). The result shows an acidic nature of leaf extracts except in case of Ruellia tuberosa . Acidic nature of leaf extracts speaks of the presence of gaseous type of air pollutants, viz. $\mathrm{SO}_{2}$ and $\mathrm{NO}_{\mathrm{X}}$ which diffuse in and form acid radicals in the leaf matrix by reacting with cellular water to finally affect the chlorophyll molecules in the process (Singh et al., 1991). Photosynthetic efficiency of a plant was reported by Türk and Wirth (1975) to be strongly dependent on leaf pH. Lower the leaf pH greater is the reduction in photosynthetic rate.

Table 4: Values of $\mathrm{pH}$ of leaf- extracts of the species selected for the present study.

\begin{tabular}{|l|l|l|}
\hline Sl. No. & Name of the species & pH of Leaf extract \\
\hline 1 & Alternanthera sessilis (L.) R.Br. ex DC. & 4.79 \\
\hline 2 & Antigonon leptopus Hook. \& Arn. & 6.91 \\
\hline 3 & Boerhavia repens L. & 7.03 \\
\hline 4 & Desmodium gangeticum (L.) DC. & 7.48 \\
\hline 5 & Elephantopus scaber L. & 7.55 \\
\hline 6 & Globba bulbifera Roxb. & 6.57 \\
\hline 7 & Oplismenus compositus (L.) P.Beauv. & 6.86 \\
\hline 8 & Ruellia tuberosa L. & 8.16 \\
\hline 9 & Tridax procumbens (L.) L. & 6.87 \\
\hline 10 & Vitis reticulata M.A. Lawson & 3.53 \\
\hline
\end{tabular}

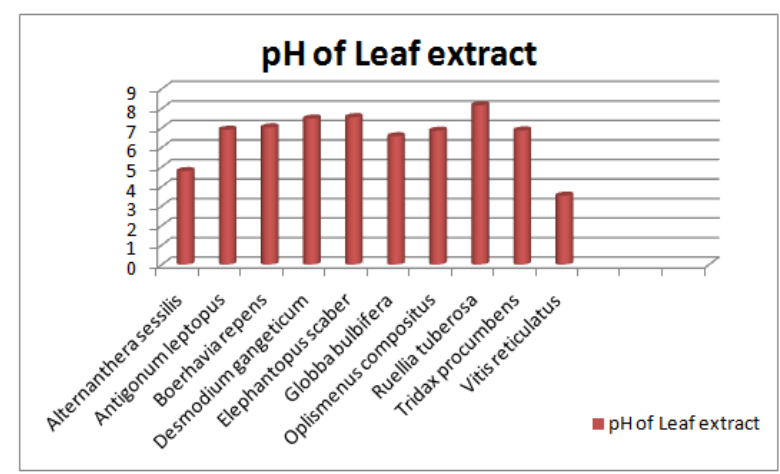

Figure 5: Bar graph representing the $\mathrm{p}^{\mathrm{H}}$ of the leaves of the species selected for the present study. 
Table 5: Analysis of Air Pollution Tolerance Index (APTI) of the selected plant species

\begin{tabular}{|c|c|c|c|c|c|c|}
\hline SI. No & Name of the species & $\begin{array}{l}\text { Total } \\
\text { Chlorophyll (T) }\end{array}$ & $\begin{array}{l}\text { Relative water } \\
\text { content }(R)\end{array}$ & $\begin{array}{l}\text { Ascorbic acid } \\
\text { Concentration (A) }\end{array}$ & $\begin{array}{l}\text { pH of Leaf } \\
\text { extract }(P)\end{array}$ & APTI \\
\hline 1 & $\begin{array}{l}\text { Alternanthera sessilis (L.) } \\
\text { R.Br. ex DC. }\end{array}$ & 0.008 & 88.42 & 55.26 & 4.79 & 35.35 \\
\hline 2 & $\begin{array}{l}\text { Antigonon leptopus Hook. \& } \\
\text { Arn. }\end{array}$ & 0.651 & 74.88 & 71.05 & 6.91 & 61.20 \\
\hline 3 & Boerhavia repens L. & 0.007 & 69.82 & 55.26 & 7.03 & 45.86 \\
\hline 4 & $\begin{array}{l}\text { Desmodium gangeticum (L.) } \\
\text { DC. }\end{array}$ & 0.843 & 76.47 & 52.63 & 7.48 & 51.45 \\
\hline 5 & Elephantopus scaber L. & 0.170 & 92.4 & 42.105 & 7.55 & 41.74 \\
\hline 6 & Globba bulbifera Roxb. & 0.006 & 88.61 & 57.89 & 6.57 & 46.92 \\
\hline 7 & $\begin{array}{l}\text { Oplismenus compositus (L.) } \\
\text { P.Beauv. }\end{array}$ & 0.089 & 83.83 & 52.63 & 6.86 & 44.95 \\
\hline 8 & Ruellia tuberosa $\mathrm{L}$. & 0.407 & 89.78 & 55.26 & 8.16 & 56.31 \\
\hline 9 & Tridax procumbens (L.) L. & 0.028 & 82.35 & 52.63 & 6.87 & 44.53 \\
\hline 10 & $\begin{array}{lll}\text { Vitis } & \text { reticulata } & \text { M.A. } \\
\text { Lawson } & & \end{array}$ & 0.069 & 89.86 & 65.78 & 3.53 & 32.66 \\
\hline
\end{tabular}

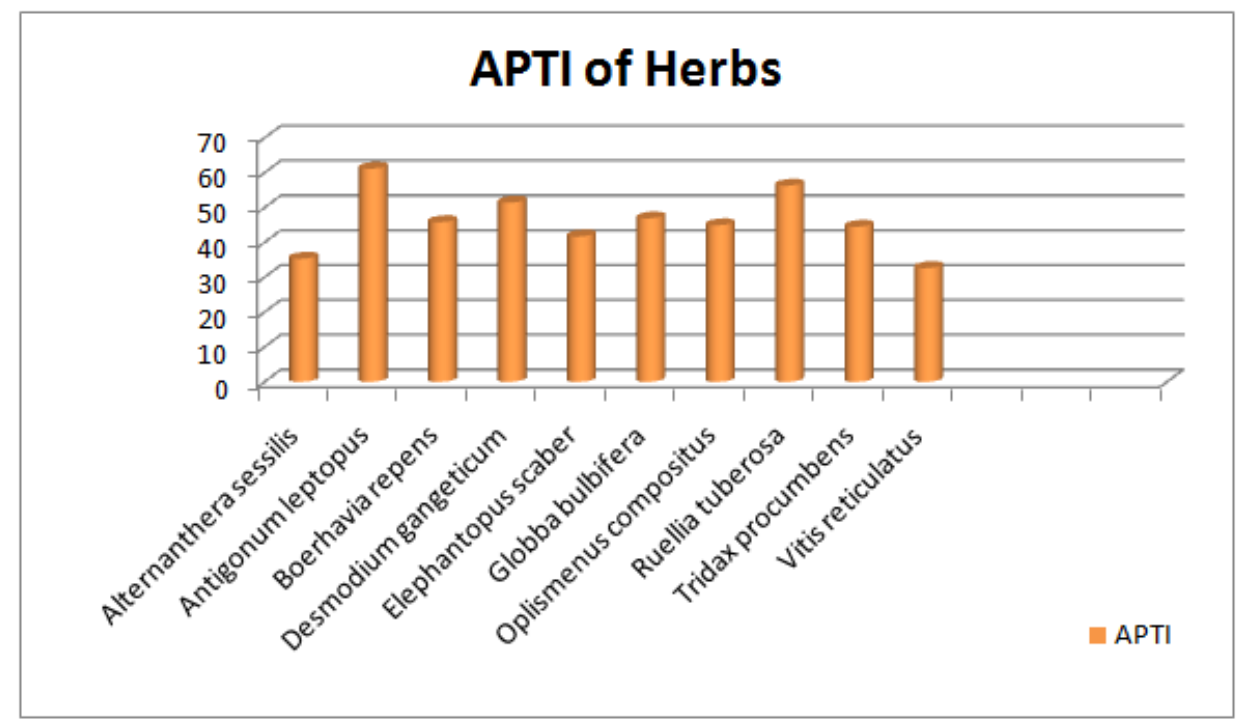

Figure 6: Bar graph representing the APTI values of the plant species

In the present study APTI is calculated for ten plant species growing in Golapbag campus of (Table 5) Burdwan University wherefrom it is evident that all the species have scored vey high values of APTI ranging from 32.66 (Vitis reticulates) to 61.20( Antigonon leptous). Antigonon leptous, a non-ochreate climber of Polygonaceae is the best in the lot being successively followed by Ruellia tuberosa and Desmodium gangeticum (Fig.6). All species being tolerant are likely to qualify for getting used as pollution "sink" and therefore a number of environmental benefits can be derived from planting these satisfactorily tolerant species in polluted areas in Burdwan and elsewhere.

\section{Conclusion}

Based on the present study it can be concluded that the APTI values determined with the help of four biochemical parameters such as chlorophyll, ascorbic acid, relative water content and $\mathrm{p}^{\mathrm{H}}$ can be use as predictor of plant resilience to air pollution and hence in monitoring air quality. Plants for being continuously exposed to pollutants accumulation of pollutants cannot be avoid as has been the case in the present study. In our study, all the species were found to be tolerant among them Antigonon leptopus (61.20) exhibited highest APTI value successively followed by Ruellia tuberosa (56.31), Desmodium gangeticum (51.45) and Globba bulbifera (46.92). It is noteworthy that all the tested species are silent scavangers without even showing any teratological changes. As such these non woody species can be recommended for planting in parks or garden especially in urban or industrial areas.

\section{Acknowledgements}

Authors are grateful to Department of Botany, Burdwan University for providing Laboratory facilities. One of the authors is grateful to UGC-CAS for financial assistance. 


\section{References}

[1]. A Mukherjee, Plant - An indicator and mitigator of pollution, Indian Science Cruiser, 7(3), 1993, 11-17.

[2]. F.J. Escobedo, J.E. Wagner, and D.J. Nowak, Analyzing the cost effectiveness of Santiago, Chile's policy of using urban forests to improve air quality, Journal of Environmental Management, 86, 2008, 148-157.

[3]. P.M. Mashita, and V. L. Pise, Biomonitoring of air pollution by correlating the Pollution Tolerance of some commonly grown trees of an urban area, Pollution Research, 20(2), 2001, 195-197.

[4]. G. V. Subrahmanyam, D. N. Rao, C. K. Varshney, and D. K. Biswas, Air pollution and Plants: A state of the art report (Ed.), Ministry of Environment and forests, 1985, 146-171.

[5]. D. Namhata, and A. Mukherjee, An enumeration of the angiosperms in the campus of University of Burdwan. Journal of Economic and Taxonomic Botany, 14(1), 1990, 41-47.

[6]. T. Ghosh, and A. Mukherjee, Evaluation of some plant species in biomonitoring air pollution, Env. and Ecol, 21 (4), $2003,747-751$.

[7]. G. Hotwani, and A. Mukherjee, Studies on medicinal plants of Burdwan University campus, J. Botan. Soc. Bengal, 59 (1\&2), 2005a, 13-22.

[8]. G. Hotwani, and A. Mukherjee, Inventorization of plants growing in Burdwan University Campus on the basis of diseases cured by them. Indian J. Applied and Pure Bio., 20 (1), 2005b, 59-66.

[9]. M. Das, and A. Mukherjee, Carbon sequestration potential, its correlation with height and girth of selected trees in the Golapbag campus, Burdwan, West Bengal (INDIA), Indian J.Sci.Res,.10(1), 2015, 53-57.

[10]. S. Ganguly, and A. Mukherjee, A census of the tree species in the Golapbag campus of Burdwan University, West Bengal (India) with their IUCN red list status and Carbon sequestration potential of some selected species, 2016.

[11]. P. L. Conklin, Recent advances in the role and biosynthesis of ascorbic acid in plants, Plant Cell Environment, 24, 2001, 383-394.

[12]. F. Scholz, and S. Reck, Effects of acids on forest trees as measured by titration in vitro, Inheritance of buffering capacity in Picea abies, Water, Air and Soil Pollution, 8, 1977, 41-45.

[13]. D.I. Arnon, Copper enzymes in isolated chloroplasts, Polyphenoloxidase in Beta vulgaris, Plant Physiol, 24, 1949, 1-15.

[14]. G. McKinney, Absorption of light by chlorophyll solutions, J. Biol. Chem, 140, 1941, 315-322.

[15]. H. D. Barrs, and P. E. Weatherley, A re-examination of the relative turgidity technique for estimating water deficits in leaves, Aust. J. Biol. Sci,. 15, 1962, 413-428.

[16]. S. K. Jagota, and H. M. Dani, A new colorimetric technique for the estimation of vitamin C using Folin phenol reagent, Analytical biochemistry, 127(1), 1982, 178-182.

[17]. S. K. Singh, and D. N. Rao, Evaluation of plants for their tolerance to air pollution. In Proc. Symp. on Air pollution control, IIT, Delhi, 1983, 218-224.

[18]. Y. Kalyani, and M. A. Singaracharya, Biomonitoring of air pollution in Warangal city, Andhra Pradesh, Acta Botanica indica, 23(1), 1995, 21-24.

[19]. W. Dedio, Water relations in wheat leaves as screening test for drought resistanc,. Canadian Journal of Plant Science, 55, 1975, 369-378

[20]. S.K. Singh, D.N. Rao, M. Agrawal, J. Pandey, and D. Narayan, Air Pollution Tolerance index of plants, Journal of Environmental Management, 32, 1991, 45-55.

[21]. R. Türk, and V. Wirth, The pH dependence of SO2 damage to lichens, Oecologia, 19, 1975, $285-291$. 